\title{
PEMBENTUKAN KARAKTER KEPEMIMPINAN PROFETIK BERBASIS TRILOGI KEPEMIMPINAN KI HAJAR DEWANTARA MELALUI KEGIATAN KEPRAMUKAAN
}

\author{
Novi Ariyanti' ${ }^{1}$ Unun Zumairoh Asr Himsyah ${ }^{2}$ \\ ${ }^{1}$ Institut Agama Islam Darullughah Wadda'wah Pasuruan, Indonesia \\ ${ }^{2}$ Institut Agama Islam Darullughah Wadda'wah Pasuruan, Indonesia \\ Email: noviariyanti2017@gmail.com ${ }^{1}$, ununzumairoh@gmail.com²
}

\begin{tabular}{l|l|l} 
Received: April 2021 & Accepted: Juni 2021 & Published: Juli 2021
\end{tabular}

\begin{abstract}
This research is motivated by the unique activities of scouts at SMA 45 Purwodadi which are oriented to the formation of leadership characters. The research method used is descriptive qualitative with a case study approach. Through data collection techniques using interviews, observation and documentation, the research seeks to reveal the system used in the formation of leadership character, along with the supporting and inhibiting factors. The results show that the implementation of scouting activities uses the 'Among' system which reflects the trilogy values of 'Ing Ngarso sung Tulodo, Ing madya mangun Karso and Tut wuri Handayani', meaning that the front gives an example, the middle gives encouragement and the back always encourages. The leadership character is strived to be formed through 5 activities: 1) unit leader rehearsal 2) upgrading, seminars and workshops, 3) Persami 4) Community service camp, and 5) Scout Action Unit (SAKA), so that a prophetic leadership character is formed by increasing knowledge, skills, and abilities. experience and life skills, which adhere to the characteristics of the Prophet, namely 'Shidiq', 'Amanah', 'Tabligh' and 'Fathanah'. Support and commitment from schools, reliable and experienced scout coaches and synergistic relationships are supporting factors in the formation of leadership characteristics. Meanwhile, student motivation and lack of infrastructure are part of the inhibiting factors that become the material for evaluation and improvement for SMA 45 Purwodadi.
\end{abstract}

Keywords: prophetic leadership, Ki Hajar Dewantara leadership trilogy, scouting activities

\begin{abstract}
Abstrak: Penelitian ini dilatarbelakangi oleh uniknya kegiatan pramuka di SMA 45 Purwodadi yang berorientasi pada pembentukan karakter kepemimpinan. Metode penelitian yang digunakan adalah deskriptif kualitatif dengan pendekatan studi kasus. Melalui teknik pengumpulan data menggunakan wawancara, observasi dan dokumentasi, penelitian berupaya mengungkap sistem yang digunakan dalam pembentukan karakter kepemimpinan, beserta faktor pendukung dan penghambatnya. Hasil penelitian menunjukkan bahwa pelaksanaan kegiatan kepramukaan menggunakan sistem Among yang mencerminkan nilai trilogi Ing Ngarso sung Tulodo, Ing madya mangun Karso dan Tut wuri Handayani, artinya di depan memberi contoh, di tengah memberikan dorongan dan di belakang selalu menyemangati. Karakter kepemimpinan diupayakan terbentuk melalui 5 kegiatan: 1) Gladian pimpinan satuan 2) penataran, seminar dan lokakarya, 3) Persami 4) Perkemahan Bakti, dan 5) Satuan Aksi Pramuka (SAKA), sehingga terbentuk karakter kepemimpinan profetik dengan meningkatkan pengetahuan, keterampilan, pengalaman dan life skill, yang berpegang pada sifat-sifat Rasulullah yakni Shidiq, Amanah, Tabligh dan Fathanah. Dukungan dan komitmen dari sekolah, pembina pramuka yang handal dan berpengalaman serta hubungan yang sinergis menjadi faktor pendukung dalam pembentukan karakter kepemimpinan. Sedangkan motivasi siswa dan kurangnya sarana prasarana merupakan bagian dari faktor penghambat yang menjadi bahan evaluasi dan perbaikan bagi SMA 45 Purwodadi.
\end{abstract}

Kata Kunci: kepemimpinan profetik, Trilogi kepemimpinan Ki Hajar Dewantara, kepramukaan 


\section{A. Pendahuluan}

Kepemimpinan merupakan konsep yang esensial dalam tatanan kehidupan. Kepemimpinan tidak hanya dipandang sebagai kecakapan dan keterampilan seseorang dalam menduduki sebuah jabatan atau tugas, namun diyakini sebagai sebuah bentuk tanggung jawab dalam memaksimalkan sumber daya yang ada. Tanggung jawab tersebut harus tercermin melalui sosok pemimpin yang handal, profesional dan memiliki pengaruh yang positif bagi organisasi. Dewasa ini Indonesia dilanda krisis kepemimpinan hingga Komisi Pemberantasan Korupsi (KPK) mencatat ada sembilan kepala daerah yang terjerat kasus korupsi melalui OTT (operasi tangkap tangan) di tahun 2019 mulai dari kalangan Kementerian, anggota DPR hingga pejabat daerah. ${ }^{1}$ Kasus kasus tersebut menyita perhatian publik dan sangat memprihatinkan. Jelas sekali di situasi seperti ini pihak yang sangat dirugikan adalah rakyat. Krisis kepemimpinan di atas adalah tugas besar untuk segera disikapi dan diselesaikan, karena pada hakikatnya setiap manusia adalah pemimpin, dan setiap pemimpin akan dimintai pertanggungjawabannya kelak, meski hanya memimpin dirinya sendiri.

Untuk menyikapi krisis tersebut maka dibutuhkan tindakan yang fundamental yakni melalui pendidikan. Pendidikan dapat menjadi aspek yang mampu membentuk karakter generasi bangsa yang cerdas secara spiritual, emosional dan intelektual. Maka untuk mewujudkan pendidikan yang mengemban amanah undang-undang penanaman karakter diperlukan adanya kolaborasi antar seluruh elemen. Unsur pemerintah, pendidikan dan tenaga kependidikan, orang tua dan masyarakat. Dalam UU nomor 20/2003 tentang Sistem Pendidikan Nasional, Permendiknas nomor 22/2006 tentang Standar Isi, Permendiknas nomor 23/2006 tentang SKL, Inpres nomor 1/2010 tentang Percepatan Pelaksanaan Prioritas Pembangunan Nasional Tahun 2010 menyatakan/menghendaki/memerintahkan pengembangan karakter peserta didik melalui pendidikan di sekolah. ${ }^{2}$

UU No 20 Tahun 2003 Tentang Sistem Pendidikan Nasional pada Pasal 3, yang menyebutkan bahwa pendidikan nasional berfungsi mengembangkan kemampuan dan membentuk karakter serta peradaban bangsa yang bermartabat dalam rangka mencerdaskan kehidupan bangsa. Pendidikan nasional bertujuan untuk berkembangnya potensi peserta didik agar menjadi manusia yang beriman dan bertakwa kepada Tuhan Yang Maha Esa, berakhlak mulia, sehat, berilmu, cakap, kreatif, mandiri, dan menjadi warga negara yang demokratis serta bertanggung jawab. ${ }^{3}$

\footnotetext{
1 Kumparan, “Kinerja KPK di 2019: 21 OTT hingga Jerat 146 Tersangka," kumparan, diakses 1 Juli 2021, https://kumparan.com/kumparannews/kinerja-kpk-di-2019-21-ott-hingga-jerat-146-tersangka1 tssjLwflDD.

2 Pramuka Indonesia, "Landasan Hukum Gerakan Pramuka Indonesia," diakses 1 Juli 2021, https://www.pramukaindonesia.com/2014/11/landasan-hukum-gerakan-pramuka-indonesia.html.

3 Presiden Republik Indonesia, "Undang-undang Republik Indonesia nomor 20 tahun 2003 tentang sistem pendidikan nasional," Jakarta: Pemerintah Republik Indonesia, 2003.
} 
Sementara itu, revolusi mental yang digalakkan oleh pemerintah menjadi bagian dari strategi dalam menguatkan karakter bangsa untuk diterapkan dalam semua sendi kehidupan. Hal ini yang kemudian menjadi indikator bagi Kemendikbud untuk mencantumkan pendidikan karakter dalam muatan kurikulum. Pendidikan karakter merupakan hal yang mendasar bagi perkembangan kepribadian seseorang. Lingkungan yang positif dan produktif dapat mendukung bagi perkembangan emosi, spiritual dan intelektual. Jika hal ini terpenuhi maka dapat berdampak luas bagi perkembangan generasi bangsa.

Pembentukan kepribadian dipengaruhi oleh beberapa faktor, diantaranya adalah sosialisasi. Sosialisasi adalah proses belajar yang dilakukan oleh individu untuk berbuat atau bertingkah laku berdasarkan patokan yang terdapat dan diakui dalam masyarakat sekitarnya. ${ }^{4}$ Pendidikan karakter merupakan manifestasi dan harmonisasi dari olah rasa, olah pikir dan olah raga dari proses sosialisasi dengan melibatkan semua elemen baik orang tua, sekolah dan masyarakat. Pendidikan karakter menjadi bagian yang tak terpisahkan dalam aktivitas pembelajaran peserta didik. Pembelajaran tersebut terkait dengan proses perubahan tingkah laku baik kognitif, afektif dan psikomotor yang mana core dari pendidikan karakter adalah membentuk kepribadian peserta didik yang religius, mandiri, bertanggung jawab, mampu bekerja sama dengan lingkungan sehingga dapat terbentuk generasi yang mampu menjawab tantangan zaman dan mencetak pemimpin yang handal di masa depan.

Kegiatan kepramukaan yang banyak dikenal hanya sebagai kegiatan tepuk-tepuk tangan atau bernyanyi semata, adalah salah satu kegiatan ekstrakurikuler pilihan wajib lembaga untuk penanaman dan pendidikan karakter, terlebih karakter kepemimpinan. Slamet dalam Sahadi dkk. menyatakan bahwa kepemimpinan merupakan suatu kemampuan, proses, atau fungsi pada umumnya untuk mempengaruhi orang-orang agar berbuat sesuatu dalam rangka mencapai tujuan tertentu. ${ }^{5}$ Selain karena hal ini telah diamanatkan dalam Undang-undang Nomor 12 tahun 2010, Peraturan Menteri Pendidikan dan Kebudayaan RI Nomor 81A tahun 2013 tentang Implementasi Kurikulum 2013 pada Lampiran III, aktivitas kepramukaan ini juga memberikan kontribusi positif dan produktif bagi siswa baik secara spiritual, emosional, intelektual dan sosial. Hal ini selaras dengan tujuan pembentukan karakter kepemimpinan profetik berbasis Trilogi kepemimpinan Ki Hajar Dewantara melalui gerakan pramuka di SMA 45 Purwodadi.

Profetik berasal dari bahasa Inggris 'prophet' yang berarti Nabi atau Rasul.6 Oleh karena itu, kepemimpinan profetik bisa dimaknai sebagai kepemimpinan yang didasarkan kepada nilai

\footnotetext{
${ }^{4}$ Abdul Syani, Sosiologi skematika, teori, dan terapan (Jakarta: Bumi Aksara, 2007), 57.

5 Sahadi Sahadi, Otong Husni Taufiq, dan Ari Kusumah Wardani, "KARAKTER KEPEMIMPINAN IDEAL DALAM ORGANISASI," Moderat: Jurnal Ilmiah Ilmu Pemerintahan 6, no. 3 (2020): 513-24.

${ }^{6}$ Binti Nasukah, Roni Harsoyo, dan Endah Winarti, "Internalisasi nilai-nilai kepemimpinan profetik di lembaga pendidikan Islam," Dirasat: Jurnal Manajemen dan Pendidikan Islam 6, no. 1 (2020): 52-68.
} 
nilai kenabian sebagai utusan Allah. Kepemimpinan yang dicontohkan oleh Nabi dan Rasul dengan mengikuti petunjuk Allah SWT melalui pedoman hidup al -Qur'an merupakan kepemimpinan yang memiliki pengaruh terhadap umat manusia. ${ }^{7}$ Hasil penelitian Budiharto dan Himam $^{8}$ menjelaskan kepemimpinan profetik yaitu sistem aktivitas memanage, mengarahkan, membimbing, secara tulus ikhlas sebagaimana dilaksanakan oleh Nabi dan Rasul. Di mana dimensi kepemimpinan profetik terdiri dari empat aspek, yaitu sidiq (jujur / berkata benar), amanah (dapat dipercaya, menjalankan sebaik mungkin apa yang diamanatkan), tabligh (menyampaikan), dan fatanah (cerdas/ pandai).

Dalam satuan pramuka hal ini nampak dari sepuluh Dasa Dharma Pramuka dan Tri Satya yang menjadi tuntunan dan pedoman tingkah laku para pemimpin dan anggota pramuka. Konsepkonsep tersebut dapat selaras dengan konsep kepemimpinan profetik. Konsep Dasa Dharma pramuka dan Tri Satya tersebut menjadi kode etik dan referensi utama dalam pelaksanaan kepramukaan dan kehidupan sehari-hari. Ekstrakurikuler kepramukaan telah menjadi ekstrakurikuler wajib yang harus dilaksanakan oleh seluruh peserta didik di setiap satuan pendidikan. Pelaksanaan kegiatan kepramukaan sebagai ekstrakurikuler wajib tersebut didukung dengan dikeluarkannya Permendikbud RI No.63 Tahun 2014 tentang Pendidikan Kepramukaan sebagai Kegiatan Ekstrakurikuler Wajib pada Pendidikan Dasar dan Menengah.

SMA 45 Purwodadi Pasuruan adalah lembaga pendidikan tingkat atas yang melakukan upaya penanaman pendidikan karakter kepemimpinan profetik berbasis Trilogi kepemimpinan Ki Hajar Dewantara melalui gerakan pramuka. Hal ini bertujuan untuk memberikan pendidikan karakter kepemimpinan kepada peserta didik agar mempunyai jiwa kepemimpinan seperti Rasulullah SAW, dan juga berdasar trilogi kepemimpinan Ki Hajar Dewantara yang tercermin dalam kehidupan sehari-hari dengan menerapkan Dasa Dharma Pramuka dan Tri Satya.

Salah satu ayat al-Quran yang menggambarkan kepemimpinan Nabi Muhammad SAW terdapat dalam Surah Ali Imran ayat 159.

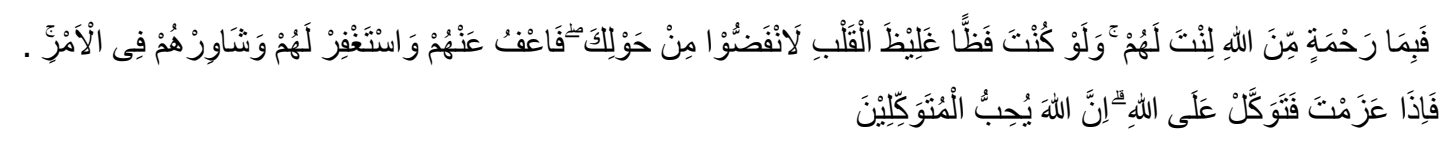

Artinya: " Maka berkat rahmat Allah engkau (Muhammad) berlaku lemah lembut terhadap mereka. Sekiranya engkau bersikap keras dan berhati kasar, tentulah mereka menjauhkan diri dari sekitarmu. Karena itu maafkanlah mereka dan mohonkanlah ampunan untuk mereka, dan bermusyawarahlah dengan mereka dalam urusan itu. Kemudian, apabila engkau telah membulatkan tekad, maka bertawakallah kepada Allah. Sungguh, Allah mencintai orang yang bertawakal. (Q.S. Ali Imran: 159).

\footnotetext{
${ }^{7}$ Luluk Maktumah dan Minhaji Minhaji, "Prophetic Leadership dan Implementasinya dalam Lembaga Pendidikan Islam," Jurnal Pendidikan Islam Indonesia 4, no. 2 (2020): 133-48.

8 Sus Budiharto dan Fathul Himam, "Konstruk teoritis dan pengukuran kepemimpinan profetik," Jurnal Psikologi 33, no. 2 (2006): 133-45.
} 
Berdasarkan ayat tersebut Djalaluddin ${ }^{9}$ menjelaskan bahwa di dalam kepemimpinan profetik terdapat niali-nilai kepemimpinan yang efektif. Nilai-nilai itu antara lain: (a) lemah lembut; (b) menghindari ucapan-ucapan yang keras dan kasar; (c) rendah hati; (d) mengampuni (d) memohon ampunan; (e) musyawarah; (f) memiliki tekad yang kuat; (g) tawakal kepada Allah SWT.

Untuk dapat melaksanakan nilai-nilai kepemimpinan sebagaimana ditanamkan oleh Rasulullah SAW. kegiatan kepramukaan SMA 45 Purwodadi menggunakan sistem 'Among,' sistem Among adalah cara pelaksanaan pendidikan di dalam gerakan pramuka yang juga merupakan hasil pemikiran Raden Mas Suwardi Suryaningrat atau yang kita kenal sebagai Ki Hajar Dewantara (KHD). Pendidikan dengan sistem 'Among' dilaksanakan dengan cara memberikan kebebasan kepada peserta didik untuk dapat bergerak dan bertindak dengan leluasa, dengan sejauh mungkin menghindari unsur-unsur perintah keharusan, paksaan, dengan maksud untuk menumbuhkan dan mengembangkan rasa percaya diri, kreativitas dan aktivitas sesuai dengan aspirasi peserta didik.

Dengan tetap berpegang pada prinsip pendidikan kepemimpinan profetik berbasis trilogi kepemimpinan Ki Hajar Dewantara (KHD), SMA 45 Purwodadi menggunakan Indikator pembentukan karakter kepemimpinan dan tanggung jawab dalam penerapan nilai-nilai Pancasila, Trisatya, Dasa Dharma Pramuka yang kemudian dituangkan dalam program kerja dan kegiatankegiatan pramuka dengan memperhatikan kebutuhan serta visi misi. Konsep pembentukan karakter kepemimpinan profetik berbasis trilogi kepemimpinan KHD ini menjadi keunikan yang layak untuk dikaji bagaimana sistem yang diterapkan, serta apa yang menjadi faktor pendukung dan penghambat pelaksanaan sistem tersebut. Hasil penelitian diharapkan dapat menjadi pijakan bagi sekolah-sekolah lain untuk dapat merumuskan aktivitas kepramukaan ini dalam menanamkan karakter kepemimpinan profetik kepada seluruh peserta didik, sehingga peserta didik dapat menjadi calon-calon pemimpin bangsa yang amanah sesuai dengan tuntunan Islam, serta sesuai dengan kode kehormatan pramuka.

\section{B. Metode Penelitian}

Penelitian ini menggunakan pendekatan penelitian kualitatif dengan jenis penelitian studi kasus. Pemilihan metode penelitian ini didasarkan pada realitas sosial maupun objeknya secara mendalam, seperti yang peneliti pergunakan untuk mengetahui bagaimana sistem pembentukan karakter kepemimpinan profetik berbasis trilogi kepemimpinan Ki Hajar Dewantara melalui

${ }^{9}$ A. Djalaluddin, Manajemen Qur'ani: Menerjemahkan Idarah Ilahiyah dalam Kehidupan (Malang: UINMaliki Press, 2014). 
kegiatan kepramukaan di SMA 45 Purwodadi Pasuruan. Serta memahami berbagai faktor pendukung dan penghambat pelaksanaan sistem tersebut.

Penelitian dilaksanakan pada bulan Januari hingga Maret 2020 dengan melibatkan sejumlah narasumber dari pihak sekolah seperti kepala sekolah, Pembina pramuka Ambalan SMA 45 dan siswa yang mengikuti ekstrakurikuler pramuka di SMA 45. Pengumpulan data penelitian kualitatif dapat dilakukan dengan beberapa macam teknik pengumpulan data yaitu wawancara, observasi dan dokumentasi .

Adapun jenis wawancara yang digunakan adalah wawancara non terstruktur bersama kepala sekolah, pembina pramuka dan beberapa siswa SMA 45. Sementara itu observasi non partisipan dipilih peneliti dikarenakan hanya mengamati kegiatan pramuka saja tanpa terjun langsung dalam anggota kelompok dan mengamati karakter peserta didik. Program kerja ekstrakurikuler pramuka, struktur kepengurusan dan video kegiatan penjelajahan, gelar aksi dan prestasi penggalang (garlang) dan apel rutin merupakan beberapa dokumen yang berhasil dihimpun oleh peneliti.

Sementara itu untuk menjamin validitas data yang telah diperoleh akan digunakan teknik triangulasi data. Triangulasi yang digunakan dalam penelitian ini yaitu triangulasi sumber dan triangulasi metode. Triangulasi sumber yaitu penggunaan sumber yang berbeda untuk menggali data yang sejenis dengan teknik pengumpulan data yang sama. Triangulasi metode yaitu penggunaan metode pengumpulan data yang berbeda-beda untuk mendapatkan data dari sumber yang sama.

Metode analisis data yang akan digunakan dalam penelitian ini adalah dengan menggunakan teknik deskripsi analisis kualitatif, yakni peneliti menggambarkan keadaan atau fenomena yang diperoleh dan kemudian dianalisis dalam bentuk kata-kata untuk memperoleh kesimpulan. Dalam penelitian ini digunakan analisis data kualitatif dari Miles et al. ${ }^{10}$ yang terdiri dari tiga alur kegiatan yang terjadi secara bersamaan, yaitu yang meliputi kondensasi data, penyajian data, dan penarikan kesimpulan.

\section{Hasil dan Pembahasan}

Penelitian ini dilaksanakan di SMA 45 siswa kelas X, XI yang mengambil kegiatan ekstrakurikuler pramuka pada semester ganjil tahun ajaran 2019-2020.

\section{Pelaksanaan Pembentukan Karakter Kepemimpinan Profetik Berbasis Trilogi Kepemimpinan Ki Hajar Dewantara}

Pembentukan Karakter Kepemimpinan Profetik Berbasis Trilogi Kepemimpinan Ki Hajar Dewantara Melalui Kegiatan Kepramukaan di SMA 45 Purwodadi Pasuruan berpegang pada Kode

10 Matthew B. Miles, A. Michael Huberman, dan Johnny Saldaña, Qualitative Data Analysis: A Methods Sourcebook, 3 ed. (United States of America: Sage Publications, Inc, 2014), 14. 
Kehormatan Pramuka. Kode kehormatan pramuka merupakan janji dan ketentuan moral Pramuka. Kode kehormatan menjadi norma kehidupan Pramuka dan memancarkan kesadaran pembangunan watak yang didapatkan peserta didik dari kegiatan kepramukaan. Satya Pramuka merupakan janji Pramuka dan Dharma Pramuka adalah ketentuan moral Pramuka Kode kehormatan bagi pramuka penegak, pramuka pandega, dan anggota dewasa yang meliputi Trisatya (janji dan komitmen diri) dan Dasa Dharma (ketentuan moral). Trisatya berbunyi:

'Trisatya Demi kehormatanku aku berjanji akan bersungguh-sungguh: menjalankan kewajibanku terhadap Tuhan Yang Maha Esa, Negara Kesatuan Republik Indonesia dan mengamalkan Pancasila, menolong sesama hidup dan ikut serta membangun masyarakat, menepati Dasadharma. Dasadharma Takwa kepada Tuhan Yang Maha Esa. Cinta alam dan kasih sayang sesama manusia. Patriot yang sopan dan kesatria. Patuh dan suka bermusyawarah. Rela menolong dan tabah. Rajin, terampil, dan gembira. Hemat, cermat, dan bersahaja. Disiplin, berani, dan setia. Bertanggung jawab dan dapat dipercaya. Suci dalam pikiran, perkataan dan perbuatan'.11

Selayaknya organisasi pada umumnya, dalam kepramukaan juga memiliki status keanggotaan dalam beberapa jenjang yakni: a) Pramuka Siaga (7-10 tahun),) dan.), b) Pramuka Penggalang, (1115 tahun), c) Pramuka Penegak (16-20 tahun dan d) Pramuka Pandega (21-25 tahun).12 Kegiatan pramuka di SMA 45 Purwodadi memasuki tahap pramuka penegak dan menjadi ekstrakurikuler wajib para siswa dari kelas X, XI,XII.

Berdasarkan wawancara dengan Pembina Pramuka di SMA 45 Kak Misbah dapat dikemukakan bahwa kegiatan rutin pramuka penegak adalah pendidikan dan pelatihan (diklat), perkemahan, upacara, latihan pengembangan kepribadian, kepemimpinan (Leadership) dan sebagainya. Sedangkan kegiatan pendukung merupakan kegiatan yang mengacu pada program kerja pramuka tingkat provinsi, kabupaten, kecamatan dan gugus depan sekolah seperti Gladian Pimpinan Sangga (DIANPINSA), Raimuna daerah dan kwartir masing masing. Pelaksana dari gugus depan yakni Kepala sekolah sebagai kepala majelis pembimbing gugus depan (KaMabigus) bersama wakil kepala sekolah bidang kesiswaan dalam hal ini disebut wakil kepala majelis pembimbing gugus depan (Waka Mabigus). ${ }^{13}$ Sementara itu wawancara dan dokumen yang diperoleh oleh peneliti dapat dikemukakan bahwa kegiatan pramuka di SMA 45 Purwodadi Pasuruan meliputi kegiatan rutin, dan kegiatan pendukung. Kegiatan rutin dilaksanakan setiap seminggu sekali pada hari Sabtu yang mengacu pada syarat kecakapan umum (SKU).14

SKU Pramuka Penegak adalah syarat-syarat kecakapan yang wajib dipenuhi oleh pramuka Penegak untuk mendapatkan Tanda Kecakapan Umum (TKU). TKU Pramuka Penegak merupakan

11 Herdi Bangkit Pandu Puri Pramana, "Pedoman Resmi Gerakan Pramuka” (Yogyakarta: Forum Tentor Indonesia, 2017), 21.

12 Reza Syehma Bahtiar, BUKU AJAR PENGEMBANGAN KEPRAMUKAAN (UWKS Press, 2018), 26.

13 Wawancara dengan pembina Pramuka (Kak Misbah), 25 Februari 2020.

14 Observasi 3 Februari 2020 
tanda kecakapan setelah memenuhi syarat-syarat kecakapan umum sesuai dengan tingkatannya. SKU pada tingkat SMA yakni penegak bantara dan penegak laksana. Komponen SKU terdiri dari lima aspek pengembangan yaitu : aspek spiritual, aspek emosional, aspek sosial, aspek intelektual dan aspek fisik. Kelima aspek pengembangan tersebut memiliki kemampuan akhir yang harus dipenuhi. Setiap dimensi pengembangan aspek dijabarkan secara berkesinambungan dan dicapai di tingkat Penegak Bantara dan Penegak Laksana. Kecakapan ini bertujuan: a) untuk memberikan pedoman dalam pengembangan diri, b) menentukan potensi yang dapat dicapai oleh setiap tingkatan Pramuka Penegak sesuai dengan usia dan sifat pribadi masing-masing, c) berfungsi sebagai dasar untuk mengetahui perkembangan pribadi. Kompetensi akhir merupakan sasaran yang diharapkan dapat dicapai setelah secara berkala. ${ }^{15}$

Pramuka Penegak menempuh syarat kecakapan umum. Dari hasil observasi di SMA 45 Purwodadi menerapkan Sistem Among dalam melaksanakan kegiatannya. Sistem Among adalah proses pendidikan yang dilaksanakan dalam bentuk hubungan khas antara peserta didik dengan pendidiknya. Sistem Among dalam Pramuka, menciptakan hubungan pendidik dengan pembina pramuka yang memberikan kebebasan kepada peserta didik (anggota Gerakan Pramuka) untuk dapat bergerak dan bertindak dengan leluasa dan menghindari paksaan, guna mengembangkan kemandirian, percaya diri, dan kreatifitas sesuai aspirasi peserta didik.

Kata "among" sendiri berasal dari bahasa Jawa yaitu "mong", "momong" atau "ngemong", yang mempunyai arti mengasuh atau membimbing. Sistem Among dilaksanakan dengan menerapkan prinsip kepemimpinan yang harus dipraktekkan oleh Pembina Pramuka. Prinsip-prinsip kepemimpinan itu terdiri atas :

a. Ing ngarsa sung tuladha yang memiliki maksud di depan menjadi teladan.

b. Ing madya mangun karsa yang memiliki maksud di tengah membangun kemauan.

c. Tut wuri handayani yang memiliki maksud di belakang memberi dorongan dan pengaruh yang baik ke arah kemandirian. ${ }^{16}$

Pelaksanaan Sistem Among dalam kepramukaan merupakan anak sistem Scouting Method (Metode Kepramukaan) yang perwujudannya akan terintegrasi dengan Prinsip Dasar Kepramukaan, Metode Kepramukaan, Kode Kehormatan Pramuka, Motto Kepramukaan dan Dasar Kepramukaan. Pramuka sebagai lembaga pendidikan luar sekolah bertujuan untuk mendidik generasi muda agar berwatak dan berbudi perkerti luhur, serta mampu mengembangkan kepribadian, potensi dan jati dirinya, sebagai tunas bangsa yang masih dalam masa transisi, sehingga pada saatnya nanti dapat mencapai proses kedewasaan dalam arti sebenarnya. ${ }^{17}$ Selain

15 Susi Yuliati, ed., Panduan Penyelesaian Syarat Kecakapan Umum Pramuak Golongan Penegak (Jakarta: Kwartir Nasional Gerakan Pramuka, 2011), 9.

${ }^{16}$ Suparto Rahardjo, Ki Hajar Dewantara: Biografi Singkat, 1889-1959 (Yogyakarta: Garasi, 2009 ), 74.

17 Yuliati, Panduan Penyelesaian Syarat Kecakapan Umum Pramuka Golongan Penegak. 
itu gerakan Pramuka juga bertujuan untuk : a) menanamkan dan menumbuhkan budi pekerti luhur dengan cara memantapkan mental, moral, fisik, pengetahuan, keterampilan, dan pengalaman melalui kegiatan, b) memupuk dan mengembangkan rasa cinta dan setia kepada tanah air dan bangsa, c) menumbuhkan pada para anggota rasa percaya diri, sikap dan perilaku yang kreatif dan inovatif, rasa bertanggungjawab dan disiplin, d) menumbuhkembangkan jiwa dan sikap kewirausahaan, e) menumbuhkan kembangkan kepemimpinan. ${ }^{18}$

Konsep penanaman karakter kepemimpinan dalam pramuka yang diterapkan di SMA 45 dapat dijelaskan sebagaimana gambar 1 .

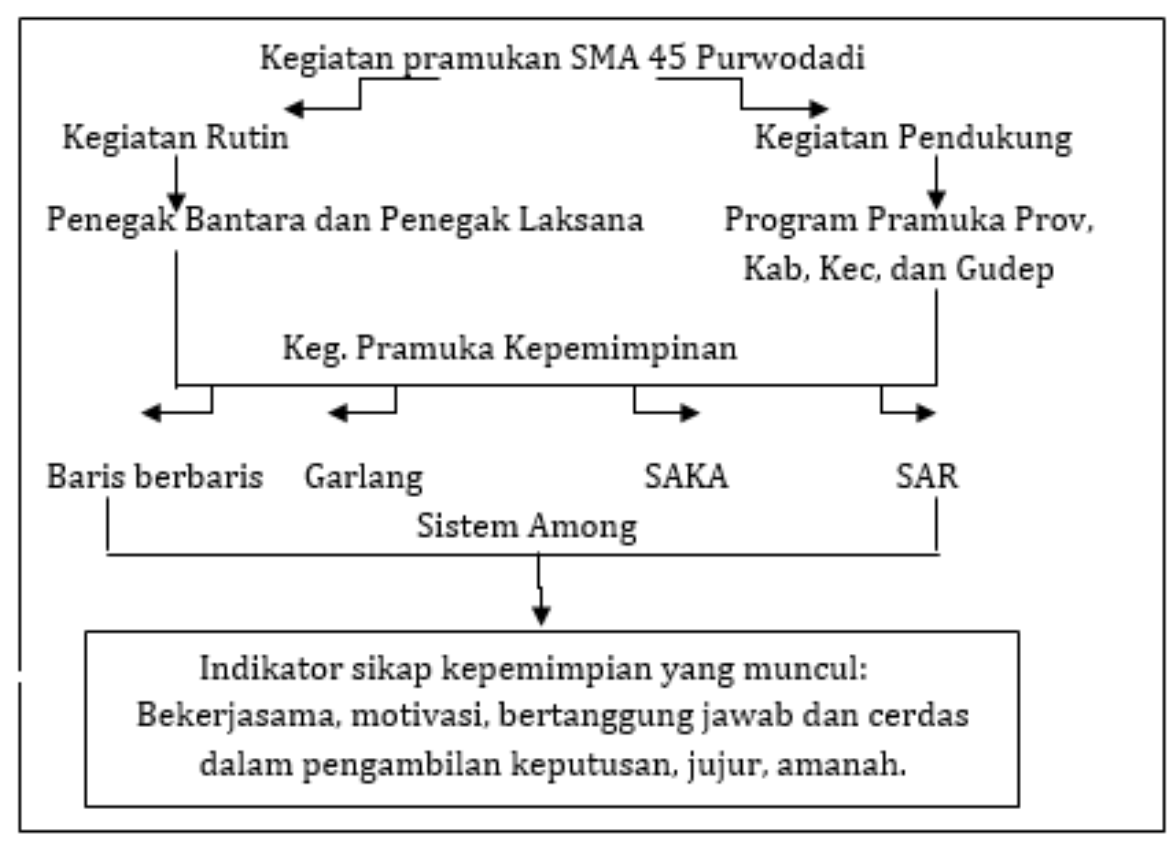

Gambar 1. Konsep Penanaman Karakter Kepemimpinan di SMA 45

Gambar 1 menjelaskan bagaimana sistem 'among' yang dilakukan dalam pembinaan pramuka di SMA 45 Purwodadi, dimana sistem Among dalam Pramuka adalah menciptakan hubungan pendidik dengan pembina pramuka. Di mana pembina memberikan kebebasan kepada peserta didik (anggota Gerakan Pramuka) untuk dapat bergerak dan bertindak dengan leluasa dan menghindari paksaan, guna mengembangkan kemandirian, percaya diri, dan kreatifitas sesuai aspirasi peserta didik.

Sistem Among dilaksanakan dengan menerapkan prinsip kepemimpinan yang harus dipraktekkan oleh Pembina Pramuka. Prinsip-prinsip kepemimpinan itu terdiri atas Ing ngarsa

${ }^{18}$ Adhyaksa Dault, Kursus Pembina Pramuka Mahir Tingkat Dasar (Jakarta: Kwartir Nasional Gerakan Pramuka, 2011). Hlm 22 
sung tuladha yang memiliki maksud di depan menjadi teladan, Ing madya mangun karsa yang memiliki maksud di tengah membangun kemauan, Tut wuri handayani yang memiliki maksud di belakang memberi dorongan dan pengaruh yang baik ke arah kemandirian. ${ }^{19}$

Dimensi kepemimpinan profetik yang diajarkan pada anggota pramuka di SMA 45 Purwodadi yang mengusung sifat-sifat Rasulullah yakni Shiddiq, Amanah, Tabligh dan Fathanah penerapannya nampak jelas tercermin dalam kegiatan pramuka di gugus depan SMA 45 Purwodadi diantaranya adalah : a) kegiatan baris berbaris, b) Gelar aksi dan prestasi penggalang (garlang), c) Persami, d) SAR dan e) satuan aksi pramuka (SAKA). Tujuan dan sasaran kegiatan tersebut adalah untuk pembentukan karakter dengan meningkatkan pengetahuan, keterampilan dan pengalaman dengan mendapatkan life skill. Dalam kegiatan baris berbaris dapat menanamkan sikap solidaritas tim, belajar mengikuti dan memberikan instruksi atau arahan pimpinan serta mengatur emosi. Sementara pada kegiatan Garlang, pramuka penegak dapat menjadi pemandu dan penanggung jawab terhadap event tersebut yang mana diikuti oleh pramuka penggalang lintas satuan pendidikan. Di sisi lain pelatihan Search And Rescue (SAR) merupakan bagian dari kegiatan kepramukaan yang sudah dipersiapkan agar pramuka penegak dapat terlibat dalam pertolongan dan penyelamatan terhadap keadaan darurat dan bencana alam. Kegiatan kepramukaan di SMA 45 dilaksanakan setiap hari Sabtu dan Minggu.

Berdasarkan wawancara dengan Kepala sekolah dapat dikemukakan bahwa kepala sekolah bersama waka kesiswaan dan pembina pramuka intens melaksanakan diskusi terkait program kerja kegiatan pramuka. Hal ini bertujuan untuk menentukan program kegiatan yang sesuai dengan kebutuhan siswa dan agenda rutin dari kabupaten. Prinsip kepemimpinan Ki Hajar Dewantara yang diterapkan di SMA 45 mendorong siswa untuk memiliki sikap empati dan solidaritas dalam menyelesaikan tugas.

Dengan kegiatan pramuka yang terprogram dan terstruktur mengoptimalkan siswa memiliki pengalaman produktif sehingga menjadi pedoman untuk terlibat di masyarakat nantinya. Indikator sikap kepemimpian yang muncul dalam kegiatan pramuka seperti mampu bekerjasama dengan tim, memberikan motivasi, memgambil keputusan, bertanggung jawab dan mengendalikan emosi maupun ego dapat menjadi bekal dan soft skill peserta didik untuk menjadi makhluk sosial yang bermanfaat bagi berbagai aspek kehidupan.

Kajian tentang penanaman karakter kepemimpinan profetik serta penanaman karakter kepemimpinan Ki Hajar Dewantara telah banyak dilakukan dan menunjukkan bahwa upaya-upaya yang dilakukan pada kegiatan kegiatan kepramukaan di SMA 45 sejalan dengan temuan-temuan dari penelitian terdahulu tersebut. Dapat dipahami sebelumnya bahwa kepemimpinan profetik adalah kemampuan mengendalikan diri dan mempengaruhi orang lain untuk mencapai tujuan

${ }^{19}$ Rahardjo, Ki Hajar Dewantara: Biografi Singkat, 1889-1959, 74. 
dengan tulus sebagaimana dilakukan oleh para nabi. ${ }^{20}$ Sistem 'among memberikan arah bagaimana dalam upaya mempengaruhi orang lain, harus dilaksanakan demi kebaikan bersama. Ketulusan, saling membantu dibutuhkan dalam upaya mencapai tujuan bersama. Terdapat konsep keteladanan "lead by example" menjadi salah satu dari tujuh aspek kepemimpinan. Hal ini selaras dengan konsep kepemimpinan spiritual kajian dari Tobroni (2006) ${ }^{21}$ yang menjelaskan bahwa melalui pendekatan etis dan keteladanan kepemimpinan profetik spiritual dengan konsep keilahian dapat dijalankan dengan membawa dimensi keduniawian kepada dimensi spiritual (keilahian). Kemampuan memimpin dengan tulus melalui segenap karakter dan keteladanan memberikan makna bahwa kepemimpinan dilaksanakan dengan menekankan pada kesadaran manusia, tidak dengan memaksa atau dipaksa. Pada konsep pendidikan profetik juga mengandung aspek-aspek kepemimpinan yang serupa. Prinsip yang harus dijalankan dalam upaya menjadi pemimpin dengan karakter profetik adalah bahwa pemimpin harus tidak memiliki maksud melukai dan tetap menghormati hak dari semua pihak yang dipengaruhi.

Sinapiah F dalam Senang mendeskripsikan bahwa persyaratan kepribadian yang harus dimiliki seorang pemimpin adalah: a) memiliki sifat pengakuan terhadap kemampuan anggota kelompok yang dipimpinnya, b) memiliki sifat jujur, c) memiliki kepercayaan pada diri sendiri, d) memiliki sifat penolong, e) memiliki jiwa entrepreneur, penuh inisiatif, kreatif dan dinamis, f) memiliki kemampuan dalam bidang profesi sehubungan dengan kelompok yang dipimpin. ${ }^{22}$ Jiwa kepemimpinan yang dibangun dalam kegiatan pramuka didasari oleh niat untuk menjadi penerus yang bermutu tidak hanya secara intelektual namun juga spiritual dan emosional. Dalam pelaksanaanya pembina pramuka selalu memotivasi siswa agar meluruskan niat dalam mengikuti kegiatan pramuka, hal ini bertujuan agar peserta didik membangun komitmen yang kuat untuk menjadi penegak yang berakhlakul karimah dan memiliki kepedulian yang baik dengan sesama. Hal ini sejalan dengan konsep habluminallah dan hablumminanaas.

\section{Faktor Pendukung dan Penghambat Pembentukan Karakter Kepemimpian}

Pramuka banyak memberikan kontribusi positif bagi peserta didik dalam pengembangan kepribadian dan membentuk jiwa kepemimpinan yang terintegrasi dalam berbagai kegiatan baik rutin maupun pendukung. Keberhasilan tersebut tak lepas dari dukungan dan komitmen lembaga pendidikan dalam merumuskan program kegiatan yang didasarkan pada kode etik pramuka dan kurikulum 2013. Perhatian sekolah dalam melibatkan pihak yang kompeten juga menjadi faktor pendukung dan positif dalam pembentukan karakter kepemimpinan siswa SMA 45 Purwodadi.

\footnotetext{
20 Budiharto dan Himam, "Konstruk teoritis dan pengukuran kepemimpinan profetik," 142.

21 Dalam Budiharto dan Himam, "Konstruk teoritis dan pengukuran kepemimpinan profetik."

22 Senang, Kepemimpinan dan Supervisi Pendidikan Islam (Malang: Madani, 2018), 30.
} 
Kepala sekolah sebagai kepala majelis pembimbing gugus depan (KaMabigus) bersama wakil kepala sekolah bidang kesiswaan dalam hal ini disebut wakil kepala majelis pembimbing gugus depan (Waka Mabigus) dan Pembina Gugus Depan bersinergi dalam merumuskan kegiatan pramuka yang mampu merepresentasikan nilai nilai pancasila dan visi misi sekolah.

Di sisi lain, pembina pramuka yang berpengalaman dan profesional dapat menentukan program kegiatan pramuka yang didasarkan pada kebutuhan, potensi visi misi sekolah dan kode etik pramuka. Pengalaman yang matang di dunia pramuka dan jaringan relasi yang luas melalui komunitas pramuka lintas daerah dapat memberikan inovasi dan kegiatan yang kontekstual bagi siswa khususnya dalam pembentukan karakter kepemimpinan.

Sementara itu, faktor penghambat yang muncul adalah lemahnya motivasi dan komitmen beberapa siswa dalam mengikuti kegiatan pramuka. Hal ini perlu dibangun komunikasi oleh kepala sekolah kepada peserta didik agar memiliki motivasi yang kuat mengikuti kegiatan pramuka. Komitmen siswa dalam mengikuti kegiatan pramuka sangat menentukan keaktifan dan antusias mereka dalam setiap program. Selain itu kurangnya sarana dan prasarana seperti untuk kegiatan alam cukup mempengaruhi dalam kegiatan pramuka. Dengan demikian, kedua faktor tersebut harus menjadi bahan pertimbangan dan bahan evaluasi kepala sekolah dan seluruh pihak yang terlibat dalam mengoptimalkan eksistensi kegiatan kepramukaan agar menjadi akar dalam pembentukan karakter kepemimpinan peserta didik.

\section{Kesimpulan}

Pembentukan karakter kepemimpinan profetik berbasis Trilogi kepemimpinan Ki Hajar Dewantara melalui gerakan pramuka di SMA 45 Purwodadi sangat efektif untuk dilaksanakan dalam rangka pembentukan karakter moral calon-calon pemimpin. Apalagi didukung dengan sistem yang dilaksanakan yakni sistem Among dengan menerapkan prinsip kepemimpinan yang harus dipraktekkan oleh Pembina Pramuka. Prinsip-prinsip kepemimpinan itu terdiri atas Ing ngarsa sung tuladhayang memiliki maksud di depan menjadi teladan, Ing madya mangun karsa yang memiliki maksud di tengah membangun kemauan, Tut wuri handayani yang memiliki maksud di belakang memberi dorongan dan pengaruh yang baik ke arah kemandirian. Hal ini sebagai upaya untuk pembentukan karakter kepemimpinan profetik dengan meningkatkan pengetahuan, keterampilan, pengalaman dan life skill berdasar sifat-sifat Rasulullah yakni Shidiq, Amanah, Tabligh, Fathanah yang diharapkan mampu dimunculkan dalam karakter kehidupan sehari-hari.

Saran bagi Gugus depan lembaga terkait, agar lebih meningkatkan intensitas kegiatankegiatan yang mendorong terbentuknya karakter kepemimpinan profetik sesuai dengan trilogi kepemimpinan Ki Hajar Dewantara. Dengan konsep dan perencanaan yang matang karakter peserta 
didik akan terbentuk secara tuntas dan sempurna. Saran bagi peneliti selanjutnya antara lain adalah peneliti dapat memperkaya khazanah penelitian kepemimpinan profetik dengan mengambil responden berdasarkan karakteristik demografis lain, baik dalam organisasi bisnis maupun nirlaba, untuk mendapatkan hasil kajian yang lebih komprehensif.

\section{Daftar Rujukan}

Bahtiar, Reza Syehma. BUKU AJAR PENGEMBANGAN KEPRAMUKAAN. UWKS Press, 2018.

Budiharto, Sus, dan Fathul Himam. "Konstruk teoritis dan pengukuran kepemimpinan profetik." Jurnal Psikologi 33, no. 2 (2006): 133-45.

Dault, Adhyaksa. Kursus Pembina Pramuka Mahir Tingkat Dasar. Jakarta: Kwartir Nasional Gerakan Pramuka, 2011.

Djalaluddin, A. Manajemen Qur'ani: Menerjemahkan Idarah Ilahiyah dalam Kehidupan. Malang: UINMaliki Press, 2014.

Indonesia, Pramuka. "Landasan Hukum Gerakan Pramuka Indonesia." Diakses 1 Juli 2021. https://www.pramukaindonesia.com/2014/11/landasan-hukum-gerakan-pramukaindonesia.html.

Indonesia, Presiden Republik. "Undang-undang Republik Indonesia nomor 20 tahun 2003 tentang sistem pendidikan nasional." Jakarta: Pemerintah Republik Indonesia, 2003.

Kumparan. "Kinerja KPK di 2019: 21 OTT hingga Jerat 146 Tersangka." kumparan. Diakses 1 Juli 2021. https://kumparan.com/kumparannews/kinerja-kpk-di-2019-21-ott-hingga-jerat146-tersangka-1tssjLwflDD.

Maktumah, Luluk, dan Minhaji Minhaji. "Prophetic Leadership dan Implementasinya dalam Lembaga Pendidikan Islam." Jurnal Pendidikan Islam Indonesia 4, no. 2 (2020): 133-48.

Miles, Matthew B., A. Michael Huberman, dan Johnny Saldaña. Qualitative Data Analysis: A Methods Sourcebook. 3 ed. United States of America: Sage Publications, Inc, 2014.

Nasukah, Binti, Roni Harsoyo, dan Endah Winarti. "Internalisasi nilai-nilai kepemimpinan profetik di lembaga pendidikan Islam." Dirasat: Jurnal Manajemen dan Pendidikan Islam 6, no. 1 (2020): 52-68.

Pramana, Herdi Bangkit Pandu Puri. "Pedoman Resmi Gerakan Pramuka." Yogyakarta: Forum Tentor Indonesia, 2017.

Rahardjo, Suparto. Ki Hajar Dewantara: Biografi Singkat, 1889-1959. Yogyakarta: Garasi, 2009.

Sahadi, Sahadi, Otong Husni Taufiq, dan Ari Kusumah Wardani. "KARAKTER KEPEMIMPINAN IDEAL DALAM ORGANISASI." Moderat: Jurnal Ilmiah Ilmu Pemerintahan 6, no. 3 (2020): 513-24.

Senang. Kepemimpinan dan Supervisi Pendidikan Islam. Malang: Madani, 2018.

Syani, Abdul. Sosiologi skematika, teori, dan terapan. Jakarta: Bumi Aksara, 2007. 
Novi Ariyanti, Unun Zumairoh Asr Himsyah

Yuliati, Susi, ed. Panduan Penyelesaian Syarat Kecakapan Umum Pramuak Golongan Penegak. Jakarta: Kwartir Nasional Gerakan Pramuka, 2011. 